UDC 122/129:304

DOI: https://doi.org/10.26661/hst-2020-5-82-01

\title{
TRUST: THE CREATING OF THE COMMUNICATIVE EXISTENTIAL SPACE
}

\author{
(C) ADAMENKO, NADIIA \\ National Pedagogical Dragomanov University (Kyiv, Ukraine) \\ E-mail: nadiia.adamenko@gmail.com \\ ORCID iD: https://orcid.org/0000-0001-7887-2720 \\ National Pedagogical Dragomanov University, 5, Pyrohova str., Kyiv, 01601, Ukraine \\ (C) OBLOVA, LIUDMYLA \\ National Pedagogical Dragomanov University (Kyiv, Ukraine) \\ E-mail: zbirka@ukr.net, ORCID iD: https://orcid.org/0000-0002-7872-6026 National \\ Pedagogical Dragomanov University, 5, Pyrohova str., Kyiv, 01601, Ukraine
}

\begin{abstract}
This study is relevant since in modern conditions when the community builds itself on distrust of the "total" and perceives the world as devoid integrity, trust more often is being called into question. Existing studies of an act of trust are limited to the study of its ethical or psychological essence and do not discuss the essence of trust as such. Attempting to look at the trust from the philosophical point of view taking into account the negative side of the experience, will help understand its fundamental function. This will allow building the right strategy for involving it within the conflicting position of people. And get rid of its crisis. Thus, awareness of the hallmark of trust will allow us to go beyond the usual understanding of its rational side and to perceive its hidden capabilities. Due to the relevance of the study of trust based on its true strength, the article aims to explore the experience of trust in general, considering all its meanings at the same time, avoiding the enumeration of substantive categories of trust acts. Research objectives: 1) to investigate the mechanism of action of trust in the conditions of "progress of distrust"; 2) to explore the sphere of trust in an inalienable manner, following its nature - trusting and encouraging to think trust, feeling it; 3) distinguish the problem of changing one's own attitude to the world under the influence of an actualized act of trust; 4) show the reasons and spaces that induce acts of trust. The scientific novelty is in the view of trust, as an experience that arbitrarily pushes the boundaries of each one of us and creates a gap: both for the free discovering of oneself and the easy acceptance of the other's capabilities. And comprehension of its essence by "additional space", showing the levels of fidelity to collaborative relationships. The study made it possible to conclude that trust is a persons' shaky search of his place in the world and a changeable relationship with another person, it outstrips logic with its sense and allows "unexpected good" to happen.
\end{abstract}

Keywords: absurdity, distrust, doubt, faith, moral experience, rationality, subjectivity, trust.

\section{Problem statement in general} and its connection with important scientific or practical tasks

In modern conditions when the community builds itself on distrust of the "total" and perceives the world as devoid integrity, trust more often is being called into question. In turn, suspicion even more intensely fulfills the function of cognitive attitude. G.
Hosking in the "Trust: A History" accurately states that in the western world there is a crisis of trust. Some of the certainties on which till recently we based our lives suddenly seem less certain. Today it strikes as a "subordinate", not rebelling against the "higher standing", not overthrowing it, but still surpasses it as it turns away from its power and 
relies only on itself. Especially in the conditions of "Industry 4.0" which will be noticed by such scientists as V.Voronkova, O. Punchenko, M. Azhazha: "System dynamics and system thinking do not deny the existence of nonlinear processes globalization, modernization, glocalization, hybridization, demonstrating the practical dimensions of these processes. Managing organizations with inflexible models or rigid plans is ineffective" [13, p. 193]. It shows itself the reliability of solvency in solitude. With this progress of mistrust, the program of «resurrecting the subject» is nevertheless persistently expressed, and thereby indicates the need to restore the experience of trust for a productive establishment of communication between people. Existing studies of an act of trust are limited to the study of its ethical or psychological essence and do not discuss the essence of trust as such. Attempt to look at the trust from the philosophical point of view taking into account the negative side of the experience, will help understand its fundamental function. This will allow building the right strategy for involving it within the conflicting position of people. And get rid of its crisis. Thus, awareness of the hallmark of trust will allow us to go beyond the usual understanding of its rational side and to perceive its hidden capabilities.

An analysis of recent research and publications that have led to the solution to this problem and the ones that the author relies on
In the historical and philosophical texts of thinkers of classical philosophy (Socrates, Plato, Aristotle, Saint Augustine, T. Aquinas, J. Locke, D. Hume, I. Kant, Hegel, etc.) we can trace the evolution of the concept of trust concerning the category of faith. In modern philosophy, trust is most actively explored in the socio-philosophical context, referring to the classical sources of philosophers, such as $\mathrm{M}$. Weber, E. Durkheim, P. Tillich, F. Fukuyama, etc.). The psychological nature of the concept of trust is revealed in the teachings of thinkers K. Jaspers, E. Fromm, A. Maslow, K. Rogers, and others.

As the subject of a special study, the concept of "trust" became acute for scientists in the late twentieth early twenty-first century, especially in the Western world. The problem is, in particular, that we are poorly informed about how trust and mistrust work in past societies. Therefore, we lack an empirical basis and a historical perspective that would help us discuss the current crisis, the existence of which is already difficult to deny. In particular, G.Hosking [9] states that in the modern world 'strong thin trust' - that is, entrusting major resources to institutions we know little about - has become our dominant mode of trusting, and suggests that we need to temper it with more traditional forms of trust if we are not to become an ever more distrustful society, with potentially very destabilizing consequences. Researcher B.A.Misztal [10] carries out one of the first systematic discussions of the nature of trust as a means of social 
cohesion, discussing the works of leading social theorists on the issue of social solidarity.

R.Hardin [7] explores various manifestations of trust and distrust in public life - from terrorism to the Internet, social capital to representative democracy. He shows that while today's politicians may experience a decline in the trust of the people, this is not new; distrust of the government characterized the work of the leading liberal thinkers such as David Hume and James Madison. However, the world we live in is much more diverse and interconnected than that of our ancestors, and this logically leads to a higher level of personal trust and mistrust between people. Philosopher K. Hawley [8] explores the key ideas about trust and distrust. Drawing on a wide range of disciplines, including philosophy, psychology, and evolutionary biology, she emphasizes the nature and importance of trusting and being trusted, from our intimate bonds with significant others to our relationship with the state. P. Faulkner and T. Simpson [12] conducted a thorough philosophical study of the nature of trust - from its social and political aspects to the ethics of trust. In the introduction to their publication "The Philosophy of Trust" the authors write: "This volume collects new philosophical essays on trust. By doing so, we help remedy the relative neglect that the topic has suffered in Anglophone philosophy. This neglect is especially striking when compared with the quantity of work on concepts of similar significance, such as knowledge, justice, or truth. The neglect is worth remedying because of both the importance of trust and its intrinsic interest" [12, p. 1]. However, the starting point of modern philosophical views on the concept of trust, on which this study is based, is the views of the philosopher A. Baier [5-6]. She was the one who asked the question philosophically: who should I trust, how, and why? In answering this, we should consider trust as such and evaluate moral trust from a moral point of view.

Due to the relevance of the study of trust based on its true strength, the article aims to explore the experience of trust in general, considering all its meanings at the same time. This defines the task of exploring the sphere of trust in an inalienable manner, following its nature - trusting and encouraging to think trust, feeling it.

\section{The main material research with an explanation of scientific results}

A person's ability to resort to trusting is associated with his disposition to people and the world but there are also the possibility and obligation of decency. But not absolute dedication, but dependent on a change of state. And therefore restless. That is, a person today will trust a priest who is strict and unwavering, and tomorrow - the one who hears their prayers. Therefore, immediately avoiding the substitution of a priori experience for the subject, a consciousness appears of the difference between acts of faith and trust. Not likening one to the other, the understanding of the fact that trust has a process of self-determination 
and self-realization that is different from faith. Studying the semantic analysis of these two concepts, Y. Ukolova writes: "Faith can be considered as a productive state of human consciousness that determines its value orientations and life guidelines. Trust is manifested in the specific relation of the subject to the one whom he trusts, is associated with the situational, relevant significance, and a priori reliability of the latter" [3, p. 200]. We summarize that while faith is a process of a free, absolute, inalienable attitude to what is happening and an independent, personal introduction of internal experience into reality, trust is mediated by a positive past, local interaction that occurs under specific conditions with limited input of one's understanding into the world. If faith is unreasonable and strong in its uncertainty, then trust is built on acquired experience and does not avoid dependence on the previous one.

It can be stated that comprehension of what is happening and building a connection in acts of trust occurs with a clear presence of verification, clarity, and justification for the actions of the "object" of trust. This attitude, limited by the spacetime framework and is a fixed understanding of its place in the world. So, due to the specifics of the beginning, trust is connected with fixation and is connected to the causeeffect relationship of the empirical world. It turns out that a person does not commit exceptional acts because of trust and his actions can be analyzed and explained.
Given the voiced and realizing the need of knowledge in the work of the trust, it is worth remembering that it is aimed at a specific person (or a certain group of people) and his (their) informed actions, which means that it can be implemented in solving established tasks. It is binding by the norms and is guaranteed. Trust is rational and does not require much effort. In other words, a person does not build trusting or distrustful relationships with time, another world, predetermined or "nobody". This is confirmed by definitions that claim to be normative. So: "trust is a moral and psychological category, as a cognitive attitude to the actions of another person and himself; based on the belief that this person acts correctly, and is diligent and honest ... Distrust creates suspicion, doubt, etc." [1]. In another place, trust is defined as: "expectation from a person of actions that correspond to moral behavior motives. Trust is based on knowledge of a person's character and, therefore, his probable behavior" [2]. Of course, it is noteworthy that trust is strengthened where decency of actions and relations is confirmed, and distrust in moments where profit is derived from the misfortune of another. That is, trust is oriented by the rules of morality and manifests itself in the correctness of the ideas accepted by society or an individual. And distrust feeds on self-interest and is fixed in misconduct. Therefore, those who comply with established customs are trusted. Those who do not confirm the idea of the right position causes distrust and fall under suspicion. 
Existing attempts to determine trust highlight two fundamental points. It is a property of moral experience, which is essentially changeable. Therefore, in itself is not a purely moral act. And it arises where separation occurs to eliminate it.

Realizing the relativity of trust does not in any way diminish its necessity in the objective world - in places where the contradictory nature of relations entails the transformation of one into another. Even though trust is "in vain" - it can disappear, with its help a person overcomes the "distance" with another person. And in situations of existence, it notes the human disposition to intimacy. Also, it doesn't matter that it is not able to overcome alienation and, in the case of turning away from the expected, replaces itself with its denial. The main thing is that trust allows you to relate to the unfamiliar as your own, native, that is, one that prefers the unchangeable to the changing, due to the initial disposition towards good.

It is impossible to bypass the fact that trust, unlike faith, demanding stability of relations, proceeds from an unstable foundation, and comprehends reality variably. Therefore, a person is temporarily in a state of trust and halfway displays the truth in the presence. The noticeable thing in the experience of trust is not so much the need for evidence of the moral purity of the principal as the easy substitution of oneself in denial if it is not confirmed. The person trusting inevitably hesitates - even at the time of trust and is in doubt. Trust is a shaky search for your place in the world.

And yet, the fact that trust is vulnerable, but not unnecessary in the sense of one's moral connection with other people, shows a person's ability to rely not only on perfection (and therefore completely and constantly), but also on someone who cannot live, without making mistakes, but still chooses the being of perfection. Even if it's a bold position. It also demonstrates that people, who cannot remain unchanged, try to preserve their former well-being in an untouched state.

Thus, trust is evaluative, strong, but it is not purely rational. In addition to its dependence on positive past experiences, it is disorganized. And it exists where the situation is not "regulated". Commits a lie. Therefore, in addition to the specifics, it is absurd. And with this, it helps to embody what other moral orientations are not able to realize. When an adult trusts a child in himself - this is strange, but not illusory. When a patient lies under the surgeon's knife, he is guided not only by confidence in the doctor's experience but also by luck, which is spontaneous. And the fact that someone was let down, for example, when dividing property, does not in any way stop the subsequent trust in people in contact with whom they have to go through the same division. Getting involved in a deliberately unclean affair, a person does not hope to come out "clean" but is capable of "not seeing" the known past, behave not in the wrong way of someone who has already done something reproachful. 
Each person, in living his destiny, finds himself in a certain situation and often behaves inconsistently, objectionably. Trust is triggered at the level of the arbitrariness of the situation and does not encroach on eventuality - the uniqueness of personal significance. That is, by discovering the imperfection of the sinful being's behavioral line in angular situations; it evades global opinions and sentences. So people in the process of trust can determine each other's temporary weaknesses, be betrayed, and experience further distrust, but not lose the understanding that the situation is reversible. As we know, the regular failure to fulfill the promise does not mean the irrevocable loss of a man. This person will not be trusted in the future, but they will not be executed. Therefore, if the "faulty" person manages to interrupt the experience of irresponsibility and establish the repetition of zeal, the fear will subside and one day he will again receive a task. By the way, even if we consider legal relations, researchers such Olena Nesterenko, Roman Oleksenko wrote that "A sense of responsibility is a person's conscious attitude towards his or her rights and responsibilities, understanding and assessment of his or her actions and their legal consequences. It provides for the unconditional performance of duties by all subjects of legal relations. Unfortunately, there are still many cases that testify to the weak development of this legal feeling" [11, p. 171].

Because the experience of trust works at the level of acquired (cultural) values, in its structure there is one who gives trust and one who overcomes it, forming a reputation for himself. Given this, the idea of F. Fukuyama that trust makes progress and determines the development of society by its levels becomes clear [4]. Under the specific foundation and its subject-object relationship, in trust, there still exists a "prevailing" one. And helping to approach the "distant", on the one hand, it forms disunity, united by the persistence of the fallacy of an imperfect world of people on the other hand. And yet, it is worth noting that it is the existence of disparate trustworthy that is not so weak, and not trustworthy that is not very strong - reveals not only the classification system but also establishes the boundary of weaknesses and strengths. Provides a guideline for behavior in difficult circumstances. And the unification of weakness, say, betrayal, does not happen. Also, the fact that there is one who can rely on another person and a distant distrustful one indicates that, to the extent of trust, people not only encounter superiority but are also tested for loyalty.

Trust has a strong connection with excellence and loyalty. We can say that these are two of his necessities. Moreover, superiority and loyalty are not related to each other. Loyalty manifests itself where the other is inevitably equivalent. And superiority exists within the framework of the law of hierarchy. Trust is unique because without trying to combine acts of superiority and fidelity, it can be in these two zones at the same time. That is, it can be loyal and surpass the other 
and to outline the meaning instinctively. The only thing is that in a situation of superiority he is forced to be loyal, and in a situation of loyalty it is voluntary.

Thus, a person in a state of trust can be both conscious, and therefore free, and unconscious - dependent, always maintaining dignity. And this cannot be logically explained, but it exists. Let's say that trust is the ability of consciously unconscious interaction, in which one is assigned to rely on someone and, at the same time, can do it himself.

If consciousness within the experience of trust shows favorableness obviously - as a right to equality, then the unconsciousness of a person in the experience of trust notes its positiveness in the fact that the trusting person himself shows that he can relate to another without the need to control and overcome it. Strongly remaining attached to the "prevailing", leaves behind him the power.

The trust state of a person is not fueling centers of competitiveness and maintains respect for both the similar, as well as for the different positions. Therefore, on those sites where the subordinate must take into account the presence of distance when interacting with the mentor, it is useful to activate the absurdity of the experience of trust. It will allow, without fear of the inevitability of an advantage to be with someone who controls the not ideal. That is, how to understand what has been done by him without hesitation, and sincerely express what is thought of the subject. And, accordingly, avoiding "corrosiveness", to build effective communicative interactions. After all, the trust allows sharp conversations and statements, but, at the same time, does not withstand them. And just so that it does not collapse, and with it, everything that it carries it is worth accepting (skipping), that which has "rushed" and not delay to break out "the tough" to defeat it.

The act of trust as the ability of consciously unconscious interaction leads away from arrogance to another - one who is full of knowledge, spiritual strength, and the intolerance of calm, incessantly having nothing to share, himself. It is important to note that the strangeness of the combination of mutual detachment and involvement allows the principal to act effectively: without analytics of the limits of the "I", one can strengthen oneself and not focus on certain characteristics of a person.

The ability of the trusting person in no case to prevail completely, to be always "subjective", but also not to feel depressed, is related to the fact that trust, being opened for fidelity, precedes a logical conclusion. It is the reason for its establishment, although their spaces also do not reciprocate. Although logic resists the "initiative" of thinking, in the experience of trust it breaks and obeys the erroneous. Because there is more absurd in trust than there is rationality.

The fact that logic is purely rational and trust is awash with an absurd element allows it to precede logic but not obscure it. Let's look at this by referring to "institutional trust", that is, trust in institutions. It is known that according to the education 
system, a school graduate is a person who has attained general knowledge. Accordingly, he consolidated himself in the field of cognitive abilities and interests and therefore prepared to master the profession. The fact that a student, after graduation, enters university, at first glance, is not so much an act of trust as a logical action. People consider it necessary to go to university in the future, not because law-abiding citizens come from higher education, but because those who know the chosen business graduate from there. At the same time, the experience of trust in such a solution plays the role of starting the construction of logic. After all, the fact that higher education, even though professionals also end up in courts and prisons, is not intended to generate those who break the law. Not a single university is supposed to have a department for the training of killers, mafia bosses, or swindlers. The fact that higher education, first of all, is supported by people of universal practice and therefore allows others to realize themselves in general and corrects a specialist competent in the field of a certain, but necessarily, good and necessary needed is undoubted. Of course, a person does not trust an institution as a building, but he understands what the history of the creation and functioning of the university stands for. Therefore, he does not pay attention to the fact that what is conceived fails and is not always justified. And for the sake of getting closer to the good, he first grasps at its morality, and only after that, he resorts to inferential knowledge about his daily bread.

Trust, due to the content of the semantic and, at the same time, absurd organic matter, helps to avoid objectification in collisions with the "prevailing" and therefore distant. Shows that relying on others who are inevitably stronger or incorrigibly weaker, but every time are "torn off" is not logical, but makes sense for the formation of reasonable and logical actions in the future relationship with people. Therefore, the trusting person does not focus on the presence of weakness arising from the existing "gaps" but develops the power of "subjectivity" - the continuity of consciousness. Let's say that it reaches "height" from the strong side - it establishes a relationship not based on the gap existing with the «height», but on the awareness of its distance. For example, realizing his incompetence, he will decide not to teach, but to learn. Or, realizing his modest abilities, he will not make large-scale plans. Rather focus on strengthening the existing ones. Or, having comprehended his spontaneity, he will not aim at something permanent. But, he will think about the consequences of his actions. In short, he will not force the mind to be guided by records, he will not limit it to the need to transcend the extreme and be the very "indicator".

Accordingly, while the gullible person cannot become proud, the distrustful one believes that one should judge others only from his point of view. Although he acts strictly logically, he objectively strengthens the will of superiority. 
Therefore, it is still incorrect. As it does not exclude the moment of absurdity, it still falls into dependence on the "gap". He protests the division and thereby strengthens it. Therefore, the opportunity not to prevail in the process of self-determination turns into the want to remove the "one who stands in front", "who knows more", "who is above". In such a distorted state, thoughts about capturing the highest and suppressing the weaker appear. Occupying actions and disappointing results emerge. The ever-growing arrogance of a person who is unable to trust turns "more" against him and introduces into the regular experience of the scantiness of what is happening. The higher and the lower stand against each other, and with this, the higher turns out to be illusory, and the lower thinks it has the leading position.

In the context of what's said above, it is obvious that a person in the experience of trust is not without risk. He can act not only "coherently", but also at random. And the mistrustful should be safe and not accept suddenness. And the fact that he, under the pressure of the recursion of superiority, moves away from loyalty is more than accessible thinking. Seeing more of a threat and diligently avoiding what is capable of suppressing is perfect, constantly repeating pattern of action. There is no room for the failure of a guarantee, and the matter of inerrancy rests. But the trusting person is also "careless" not only "provided" with experience. $\mathrm{He}$ also throws himself into "undesirable", admitting absurdities, mistakes, misfires. It cannot be said that he is completely ready for the inner changeability of the world or does not expect apostasy, but he can keep his uncertainty by recognizing the nature of the other - the eternal search for himself. In other words, he will face a blow and rightly - without superiority - react to it. This attitude does not repel certainty, but it does not rely on it entirely. And this proves that ahead of the mechanics of adjustment, the principal is "shaky". This means that he can be wrong and cannot oppress.

Thus, trust, being a reasonableunreasonable experience, determines the relationship of a person with the freedom of another, as with a controlled abyss. It allows you to rush into something that has no emphasis and understand this place as such that will give you a stop. That is, to act, endowing the other with the right to consolidate what is not subject to constancy and so be affirmed as a spontaneous being, but bordering on the good in general. Strangely, the presence of an absurd element in the experience of trust makes its field of action reasonable. And rationality unexpectedly defines its "stupidity". The fact that trust, under its "lack of assembly", allows one to get off the ground and see that primordiality (first of all good) saves from exceptional measures. Protects from the incorrigible. But in its checking, discretion, it suddenly loses control. It can easily appear where experience no longer confirms itself and, for example, decency will not be repeated. And with that, it will turn off the built path. 
The foregoing gives grounds to assert that trust is a shaky search for the place in the world, precisely because of the requirement to repeat the good that has been done. Its insidiousness stems not from the possibility of betrayal, but the opposite, from its half openness to the creation of good. That is the possibility of incomplete reliance on the actions of a finite being. And the revelation that inevitably follows from the verification. Only the trouble of trust is unavoidable from its structure and, by its design, by itself, supports its absurdity. And with this, it reveals the flaws of a person.

Conclusions from the study and prospects for further exploration in this direction

Summing up, we note that the study of the essence of trust from a philosophical point of view reveals its paradox. Considering not only the semantic - reasonable but also the absurd - unreasonable side of the experience, it becomes clear how through trust people recognize the power of another. And, at the same time, their responsiveness to the virtuous - they express the ability of closeness, forgiveness, risk. In addition to the studied side of trust positive and rational - revealing the dependence of a person on "recognized good", the study highlighted the negative side of trust and noted the importance of trust being a guideline for the fidelity of being without superiority. Therefore, even though trust is a person's shaky search for his place in the world and a changeable setting of relations with another person, with its feeling, it outstrips logic and allows for «unexpected

\section{СПИСОК ВИКОРИСТАНИХ ДЖЕРЕЛ}

1. Довіра. Короткий психологічний словник, 1976. К.: Вища школа. 54-55.

2. Костюк Г. С. Доверие. Краткий психологический словарь. Хрестоматия, 1974. М. : Высшая школа. 35-35.

3. Уколова Ю. С., 2008. «Вера» и «доверие» - семантика различий. Наука. Релігія. Суспільство. Донеиьк : IПШІ «Наука і освіта». 2. 192-200.

4. Фукуяма Ф., 2004. Доверие: социальные добродетели и путь к процветанию. М.: ООО «Издательство АСТ» : ЗАО НПП «Ермак». 730.

5. Baier Annette C., 1986. Trust and Antitrust. Ethics. Austin : The University of Texas at Austin. 96 (2). 231-260.

6. Baier Annette C., March 6-8, 1991. Trust. The Tanner lectures on human values. Delivered at. Princeton University. 13. 107-174.

7. Hardin, R. 2006. Trust. Cambridge : Polity Press. 206.

8. Hawley, K. 2012. Trust: A Very Short Introduction. Oxford : Oxford University Press. 121.

9. Hosking, G. 2014. Trust : A History. Oxford: Oxford University Press. 256.

10. Misztal, Barbara A. 1996. Trust in Modern Societies : The Search for the Bases of Social Order. Cambridge : Polity Press. 296.

11. Nesterenko, O., Oleksenko, Roman, 2020. Social philosophical reflection of the individual legal education philosophy as the basis for the democratic society functioning. HUMANITIES STUDIES : Collection of Scientific Papers. Zaporizhzhia: Zaporizhzhia National University. 4 (81). 165-181.

12. The Philosophy of Trust / Faulkner P., Simpson T., 2017. Oxford : Oxford University Press. 299. 
13. Voronkova, V., Punchenko, O., Azhazha, M., 2020. Globalization and global governance in the fourth industrial revolution (industry 4.0). HUMANITIES STUDIES: Collection of Scientific Papers / Ed. V. Voronkova. Zaporizhzhia: Zaporizhzhia National University. 4 (81). 182-200.

\section{REFERENCES}

1. Dovira. Korotkyy psykholohichnyy slovnyk, 1976. K.: Vyshcha shkola. 54-55.

2. Kostyuk H. S.? 1976. Doverye. Kratkyy psykholohycheskyy slovar'. Khrestomatyya. M.: Vysshaya shkola. 35-35.

3. Ukolova YU. S., 2008. «Vera» y «doverye» - semantyka razlychyy. Nauka. Relihiya. Suspil'stvo. Donets'k: IPSHI «Nauka i osvita». 2. 192-200.

4. Fukuyama F., 2004. Doverye: sotsyal'nye dobrodetely y put' k protsvetanyyu. M.: OOO «Yzdatel'stvo ACT»: ZAO NPP «Ermak». 730.

5. Baier Annette C., 1986. Trust and Antitrust. Ethics. Austin: The University of Texas at Austin. 96 (2). 231-260.

6. Baier Annette C., March 6-8, 1991. Trust. The Tanner lectures on human values. Delivered at. Princeton University. 13. 107-174.

7. Hardin, R. 2006. Trust. Cambridge: Polity Press. 206.

8. Hawley, K. 2012. Trust: A Very Short Introduction. Oxford: Oxford University Press. 121.

9. Hosking, G. 2014. Trust: A History. Oxford: Oxford University Press. 256.

10. Misztal, Barbara A. 1996. Trust in Modern Societies: The Search for the Bases of Social Order. Cambridge: Polity Press. 296.

11. Nesterenko, O., Oleksenko, Roman, 2020. Social philosophical reflection of the individual legal education philosophy as the basis for the democratic society functioning. HUMANITIES STUDIES: Collection of Scientific Papers / Ed. V. Voronkova. Zaporizhzhia: Zaporizhzhia National University. 4 (81). 165-181.

12. The Philosophy of Trust / Faulkner P., Simpson T., 2017. Oxford: Oxford University Press. 299.

13. Voronkova, V., Punchenko, O., Azhazha, M., 2020. Globalization and global governance in the fourth industrial revolution (industry 4.0). HUMANITIES STUDIES: Collection of Scientific Papers / Ed. V. Voronkova. Zaporizhzhia: Zaporizhzhia National University. 4 (81). 182-200.

АДАМЕНКО, Н. Б. - кандидат філософських наук, доцент, кафедра філософії, Національний педагогічний університет імені М.П.Драгоманова (Київ, Україна)

E-mail: nadiia.adamenko@gmail.com, ORCID iD : https://orcid.org/0000-0001-7887-2720

ОБЛОВА, Л. А. - кандидат філософських наук, доцент, кафедра філософії, Національний педагогічний університет імені М.П.Драгоманова (Київ, Україна)

E-mail: zbirka@ukr.net, ORCID iD : https://orcid.org/0000-0002-7872-6026

\section{ДОВІРА: СТВОРЕННЯ КОМУНІКАТИВНОГО ЕКЗИСТЕНЦИЙНОГО ПРОСТОРУ}

Актуальність дослідження полягає в тому, що в умовах сучасності, коли суспільство вибудовує себе на умовах недовіри до «тотального» і сприймає світ як те, що позбавлене цілісності, досвід довіри все активніше ставиться під сумнів. Так само, підозрілість ще інтенсивніше виконує функцію пізнавального ставлення. Сьогодні впадає в око те, як «підлеглий», не бунтуючи проти «керівника», не усуваючи його, все-таки перевершує його тим, що відвертається від його влади і розраховує тільки на себе. Надає собі надійність спроможності на самоті. У цьому прогресі недовіри все ж настійливо заявляється програма «воскресіння суб'єкта» i цим позначає необхідність відновлення досвіду довіри для продуктивної настанови зв'язку між людьми. Існуючі розроблення акту довіри обмежуються вивченням ï етичної або психологічної сутності і не зачіпають суті довіри як такої. Спроба подивитися на довіру з філософської точки зору, припускаючи враховувати ще й негативну сторону досвіду, дозволить зрозуміти іiі фундаментальну функцію. Це організовує можливість вибудувати правильну стратегію iї задіяння в межах суперечливого становища людей. I компенсувати в нуль ії кризу. Таким чином, усвідомлення характерної ознаки довіри, дозволить вийти за звичне розуміння іiі раціональної сторони і сприйняти її приховані можливості. У зв'язку 3 актуальністю вивчення довіри на підставах іiі реальної сили, стаття має на меті дослідити досвід довіри в цілому, передбачаючи всі іiі смисли одночасно і уникаючи перерахування предметних, змістовних ліній актів довіри. Завдання дослідження: 1) дослідити Trust: the creating of the communicative existential space 
механізм дії довіри в умовах «прогресу недовіри»; 2) представити сферу довіри не відчужено, а у співвіднесенні з іiі природою довірливо і спонукати мислити довіру, відчуваючи ऑii; 3) виділити проблему зміни свого відношення до світу під впливом актуалізації акта довіри; 4) показати причини і простори, які спонукають довіряти. Наукова новизна та висновок полягає в розумінні довіри, як досвіду, який довільно відсуває межі кожного і створює зазор: як для вільного відкриття себе, так і невимушеного прийняття можливостей іншого. І осмисленні його сутності «додатковим простором», що демонструє рівні вірності співробітницьких відносин.

Ключові слова : абсурдність, віра, довіра, моральний досвід, недовіра, раціональність, суб'єктивність, сумнів.

АДАМЕНКО, Н. Б. - кандидат философских наук, доцент, кафедра философии, Национальный педагогический университет имени М. П.Драгоманова (Киев, Украина)

E-mail: nadiia.adamenko@gmail.com, ORCID iD : https://orcid.org/0000-0001-7887-2720

ОБЛОВА, Л. А. - кандидат философских наук, доцент, кафедра философии, Национальный педагогический университет имени М.П.Драгоманова (Киев, Украина)

E-mail: zbirka@ukr.net, ORCID iD : https://orcid.org/0000-0002-7872-6026

\section{ДОВЕРИЕ: СОЗДАНИЕ КОММУНИКАТИВНОГО ЭКЗИСТЕНЦИАЛЬНОГО ПРОСТРАНСТВА}

Актуальность исследования связана с тем, что в условиях современности, когда сообщество выстраивает себя на условиях недоверия к «тотальному» и воспринимает мир как лишенный целостности, опыт доверия всё активней ставится по сомнение. В свою очередь, подозрительность ещё усиленней исполняет функцию познавательного отношения. Сегодня бросается в глаза, как «подчинённый», не бунтуя против «выше стоящего», не свергая, всё-таки превосходит его тем, что отворачивается от его власти и рассчитывает только на себя. Оказывает себе надёжность состоятельности в одиночестве. При этом прогрессе недоверия всё же настойчиво высказывается программа «воскрешения субъекта» и тем самым обозначает необходимость восстановления опыта доверия для продуктивной установки связи между людьми. Существующие разработки акта доверия ограничиваются изучением его этической или психологической сущности и не затрагивают сущности доверия как таковой. Попытка посмотреть на доверие с философской точки зрения, предполагая учитывать ещё и негативную сторону опыта, даст основание понять его фундаментальную функцию. Это организует возможность выстроить верную стратегию его задействования в рамках противоречивого положения людей. И компенсировать в ноль его кризис. Таким образом, осознание отличительного признака доверия, позволит выйти за привычное понимание его рациональной стороны и воспринять его сокрытые возможности. Цель научной разведки: в связи с актуальностью изучения доверия на основаниях его настоящей силы, статья имеет своей целью исследовать опыт доверия в целом, предусматривая все его смыслы одновременно и избегая перечисления предметных, содержательных разрядов доверительных актов. Задачи исследования: 1) исследовать механизм действия доверия в условиях «прогресса недоверия»; 2) представить сферу доверия неотчуждённо, в соответствии с его природой - доверительно и побуждать мыслить доверие, чувствуя его; 3) выделить проблему изменения собственного отношения к миру под влиянием актуализированного акта доверия; 4) показать причины и пространства, побуждающие акты доверия. Научная новизна и вывод заключается во взгляде на доверие, как опыт, который произвольно отодвигает границы каждого и создаёт зазор: как для свободного открытия себя, так и непринуждённого приятия возможностей другого. И осмыслении его сущности «дополнительным пространством», показывающем уровни верности сотруднических отношений.

Ключевые слова : абсурдность, вера, доверие, недоверие, нравственный опыт, рациональность, сомнение, субъективность.

Received date 15. 10.2020

Accepted date 17.10.2020

Published date 29.10.2020

(C) Adamenko Nadiia, Oblova Liudmyla, 2020 